\title{
DYNAMIC MODELING OF WAVE ENERGY CONVERSION SYSTEM USING HYDROSTATIC TRANSMISSION
}

\author{
NGUYEN NGOC DIEP, LE DUY TUAN, NGUYEN VIEN QUOC, LE THANH DANH
}

\author{
Industrial University of Ho Chi Minh City; \\ pdiep66@yahoo.com,leduytuan@iuh.edu.vn,nguyenvienquoc@iuh.edu.vn,le_thanh_danh@hotmail.com
}

\begin{abstract}
This paper will design a wave energy conversion model using hydrostatic transmission. Then, the optimal radius of the buoy is obtained so that wave energy capture ability of the system is maximum. In this study, the data of the wave in the Ocean such as: wave length, wave period, wave high are known. Next, Amesim and Matlab software are used for the simulation of the proposed system. The simulation results confirm that in the case of optimal buoy radius, the energy capture effectiveness of the system is better than that in the case of the random buoy radius. Finally, some conclusions are also given.
\end{abstract}

Keywords. ocean wave, energy converter, hydraulic transmission, optimal radius, wave energy capture ability.

\section{INTRODUCTION}

Nowadays, the fossil energy is running out and human are facing with lack of energy for life and production. Hence, human in over the world are trying to find new energy source for replacing fossil energy sources and renewable energy is one of the most potential energy sources for future.

Renewable energy includes a lot of difference energy source such as: solar energy, wind energy, wave energy, etc. Among the renewable energy sources, wave energy is one of the most promising sustainable sources. The research on the wave energy conversion systems have begun since 1970s [1].

In practice, three main methods of energy storage have been using in wave energy generation (WEG) so far. First of all, that is storage as potential energy in a water reservoir as studied in [1] and [2]. The second WEG method is based on the oscillating water column [3]. The third energy conversion is floating-buoy wave energy convertor [4-5], this method is paid more attention in recent year. In third method, the floating-buoy will absorb energy from the ocean wave and transfer to flow liquid at high pressure by using hydraulic system.

In this study, we will refer third method. Although some valuable investigations were obtained by adopting these floating devices, their working efficiencies were not so high. Therefore, this study focus on optimize floating-buoy system to absorb maximum wave power. The paper is arranged as following: Description of wave energy conversion system in section 2. The dynamic equation of buoy is described in section 3. Simulation result is presented in section 4. Finally, some conclusions are given in section 5.

\section{WAVE ENERGY CONVERSION SYSTEM}

This work considers a case of the floating wave energy convertor in heave only as shown in Fig.1. There are three main components including the buoy system, the hydrostatic transmission system and the generator. The wave energy is converted into the mechanical energy through the buoy system consisting of the buoy (1) which is linked with the rack and pinion mechanism (5). Here, the rack element is vertically slid via the fixed frame (2) and linear pushing (3). In addition, the kinetic energy of the buoy system is converted in to electric energy by introducing a closed-circuit hydrostatic transmission system in which it includes a two-direction fixed displacement pump (6) and a variable displacement hydraulic motor (8). The main feature of the proposed hydrostatic transmission is to store and release the energy through installing an accumulator (7) in the high-pressure line.

As known, the electrical productive efficiency is maximum when the generator is run at an optimal speed value that which is given by the manufacture. Hence, in this paper, a fuzzy sliding mode control algorithm is designed for controlling the hydraulic motor so that the generator operates at the optimal value. 


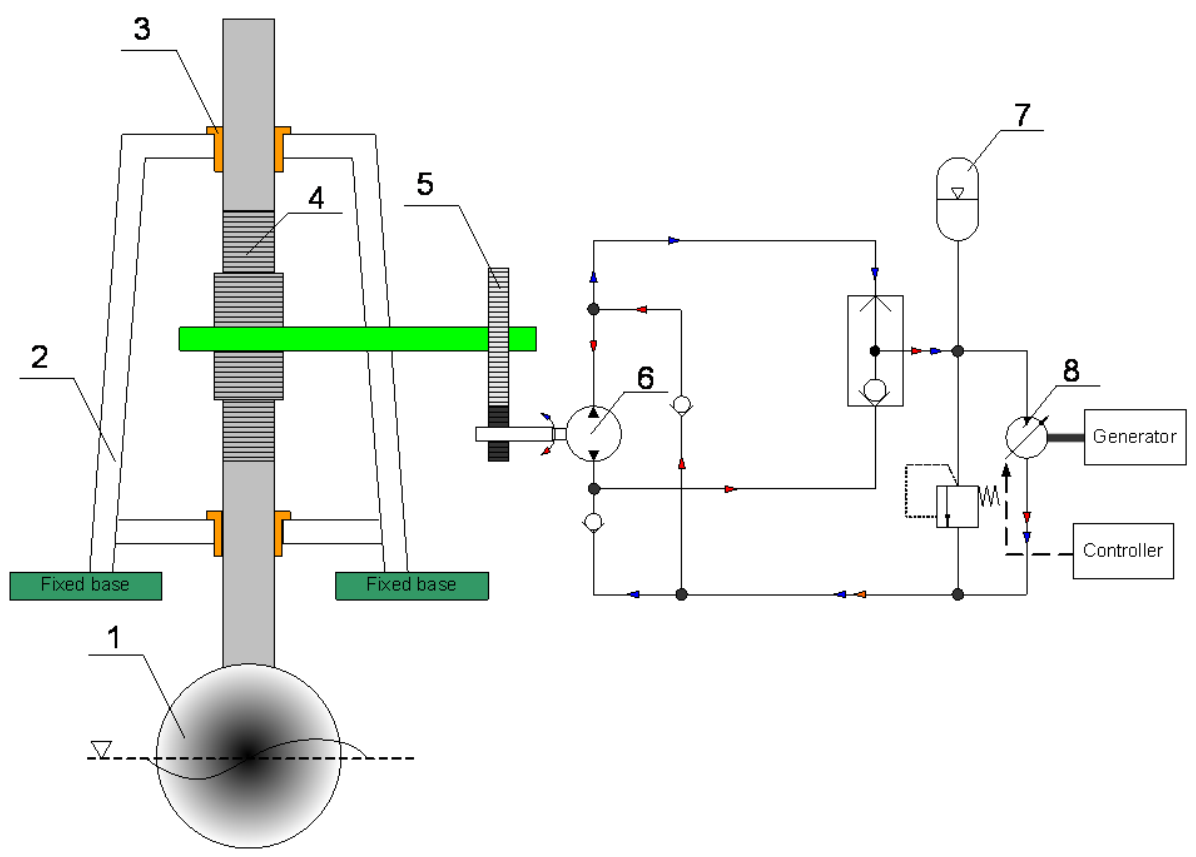

Figure 1. Structure of the wave energy conversion system.

\section{DYNAMIC EQUATION OF BUOY}

Here, the ocean wave fluctuation is regular as following

$$
x=A \sin (\omega t)
$$

where: $\mathrm{A}$ is the wave high in meter and $\omega$ is wave frequency in $\mathrm{rad} / \mathrm{s}$.

In this study, a spherical buoy with outside radius $a_{1}$, inside radius $a_{2}$.

The mass of the buoy is determined:

$$
m_{m}=\rho_{1} \frac{4 \pi}{3}\left(a_{1}^{3}-a_{2}^{3}\right)
$$

where: $\rho_{1}$ is the buoy density in $\mathrm{Kg} / \mathrm{m}^{3}$.

The dynamic equation of the buoy can be obtained as following:

$$
m_{m} \ddot{z}=F_{e}+F_{r}+F_{b}+F_{v}+F_{f}+F_{u}(\omega)
$$

where: $\mathrm{z}$ is heave motion of the buoy.

The excitation force is calculated as:

$$
F_{e}=2 \pi \rho g \pi R_{1}^{2} x / \lambda
$$

where: $\lambda$ is wave length,

$\rho$ is sea water mass density.

According to [6], The hydrostatic buoyancy force $F_{\mathrm{b}}$, the viscous force $F_{\mathrm{v}}$. The radiated force and the friction force $F_{f}$ are determined as following:

$$
\begin{aligned}
& F_{b}=-\rho g \pi R_{1}^{2} z \\
& F v=\frac{1}{2} \rho C_{d} A_{d}(\dot{z})^{2}=-R_{v} \dot{z} \\
& F_{r}=-\mu_{r} m_{m} \ddot{z}-\varepsilon \omega \rho \pi 2 R_{1}^{3} / 3 \dot{z} \\
& F_{f}=-R_{f} \dot{z}
\end{aligned}
$$

where: $R_{v}$ is viscous damping coefficient;

$C_{d}$ is drag coefficient;

$A_{d}\left(\mathrm{~m}^{2}\right)$ is projected area of the buoy, 
$\varepsilon$ and $\mu$ are coefficients which are depend on the coefficient $k R_{l}$,

$\mathrm{R}_{\mathrm{f}}$ is a friction coefficient.

Combination above equations, the dynamic equation of the buoy can be rewritten as:

$$
\left[\rho_{1} \frac{4 \pi}{3}\left(R_{1}^{3}-R_{2}^{3}\right)+\mu \rho_{1} \frac{2 \pi}{3}\left(R_{1}^{3}-R_{2}^{3}\right)\right] \ddot{z}+\left[R_{v}+R_{f}+\frac{\varepsilon \omega \rho \pi 2 R_{1}^{3}}{3}\right] \dot{z}+S_{b} z=k \rho g R_{1}^{2} x
$$

In this particular case, in order to obtain maximum absorbed power the system's natural frequency $\omega_{\mathrm{n}}$ is equals the frequency $\omega$ of the wave. This can be achieved by selecting the suitable radius as:

$$
\omega_{n}=\omega \Leftrightarrow \sqrt{\frac{\rho g \pi R_{1}^{2}}{\frac{\rho_{1} 2 \pi\left(R_{1}^{3}-R_{2}^{3}\right)}{3}(2+\mu)}}=\omega
$$

In addition, when the buoy in semi-submerged status, the Archimedes force should be equal gravity of the buoy as below:

$$
\begin{aligned}
& F_{A}=m_{m} \cdot g \Leftrightarrow \frac{2}{3} \pi \rho R_{1}^{3} g=\frac{4}{3} \pi \rho_{1}\left(R_{1}^{3}-R_{2}^{3}\right) g \\
& \Leftrightarrow \rho a_{1}^{3}=2 \rho_{1}\left(R_{1}^{3}-R_{2}^{3}\right)
\end{aligned}
$$

\section{SIMULATION}

\subsection{System model design}

In order to assess the energy conversion efficiency of the proposed system, the model of the wave energy conversion system using the hydrostatic transmission is developed in co-simulation environment which is a combination of Amesim software R13 and Matlab/Simulink software, version R2013b. Here, the buoy system are built in Simulink (see in Fig.2) and embedded in Hydrostatic transmission, which is developed in Amesim as shown in Fig.3

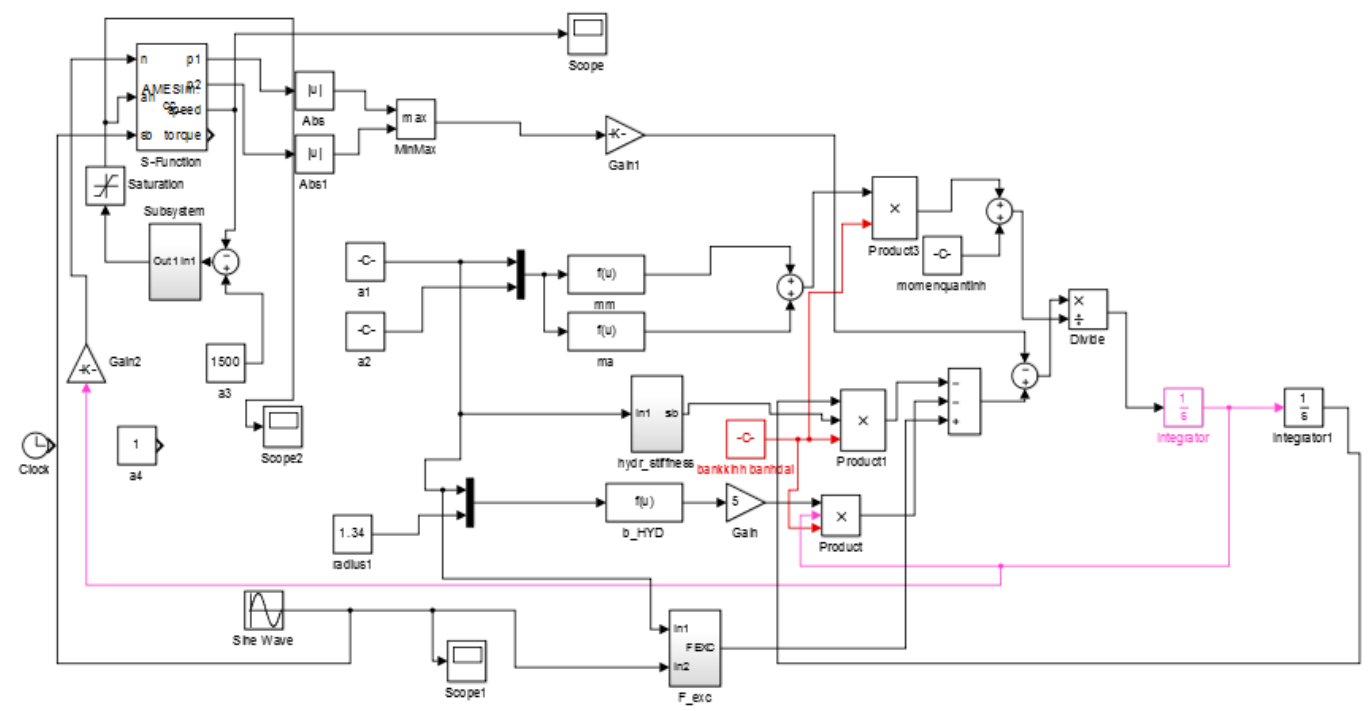

Figure 2. Modeling system build in MATLAB/Simulink 


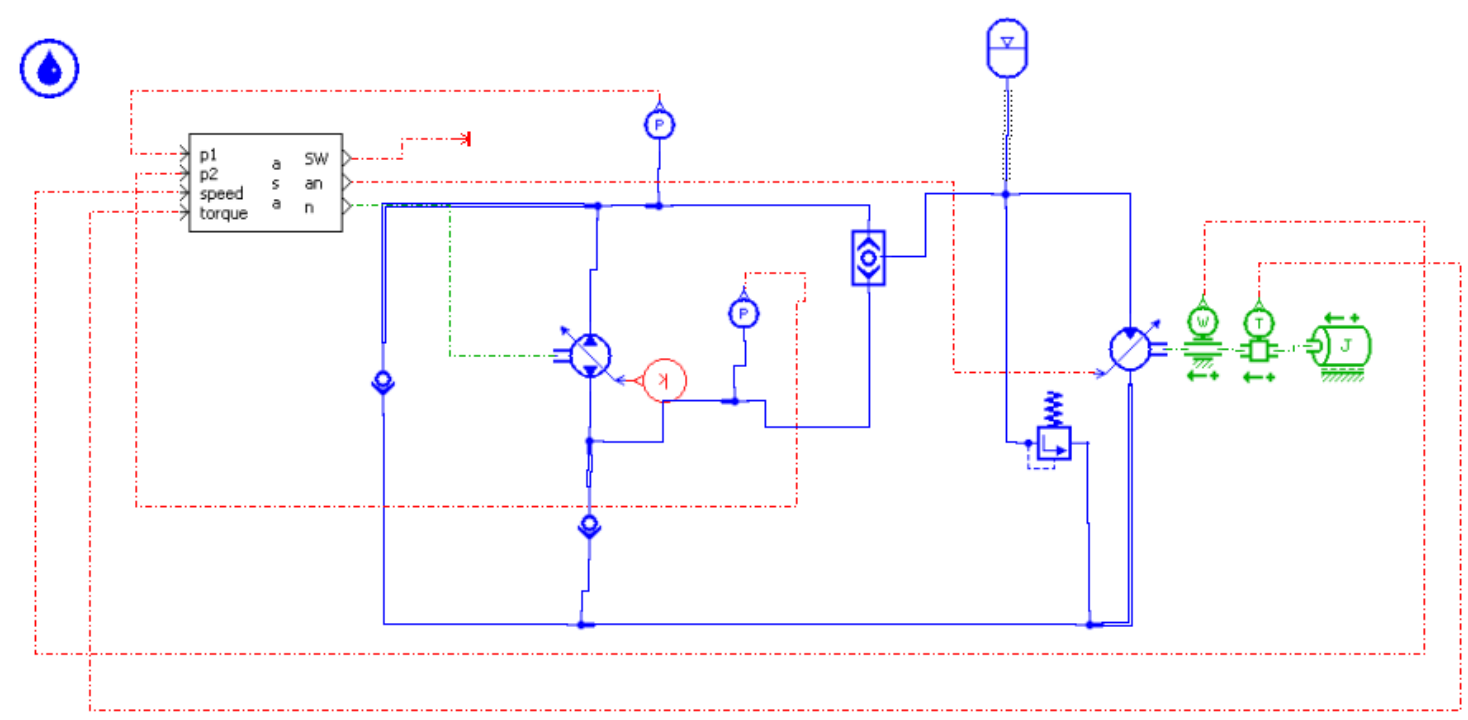

Figure 3. Modeling system build in AMESim integrated Simulink

\subsection{Simulation result}

The simulations are realized with parameters shown in Table 1.

Table 1: Simulation result

\begin{tabular}{|c|c|l|}
\hline Specification & Value & \multicolumn{1}{c|}{ Description } \\
\hline$R_{p}$ & $0.1 \mathrm{~N} \cdot \mathrm{m} / \mathrm{rev}$ & Viscosity coefficient of the pump \\
\hline$\alpha_{p}$ & 1 & Swash angle coefficient of Pump $\left(0<\alpha_{p} \leq 1\right)$ \\
\hline$D_{p}$ & $426 \mathrm{cc} / \mathrm{rev}$ & Displacement of the pump \\
\hline$R_{g}$ & $0.1 \mathrm{~N} \cdot \mathrm{m} / \mathrm{rev}$ & Viscosity coefficient of the generator \\
\hline$\alpha_{m}$ & 0.6 & Swash angle coefficient of the generator $\left(0<\alpha_{m} \leq 1\right)$ \\
\hline$D_{m}$ & $500 \mathrm{cc} / \mathrm{rev}$ & Displacement of the motor \\
\hline$\eta_{p}$ & 1 & Volumetric coefficient of the pump \\
\hline$\eta_{m}$ & 1 & Volumetric coefficient of the motor \\
\hline $\mathrm{A}$ & $0.75 \mathrm{~m}$ & Wave high \\
\hline $\mathrm{T}$ & $4.5(\mathrm{~s})$ & Wave period \\
\hline$\lambda$ & $30(\mathrm{~m})$ & Wave length \\
\hline $\mathrm{W}_{w}$ & $11.6(\mathrm{~m})$ & Wave width \\
\hline & & \\
\hline
\end{tabular}

a. Random radius buoy

In this case, the geometric parameter of buoy is randomly selected as following: $\mathrm{a} 1=5.8(\mathrm{~m}), \mathrm{a} 2=5(\mathrm{~m})$. The simulation result is shown in Fig.4. Here, Fig.4a is comparison between wave fluctuation and buoy motion, it is seen thatthe amplitude of the buoy motion is much smaller than amplitude of Wave fluctuation. Therefore, energy captured from this buoy is very low as shown in Fig.4b. 
a

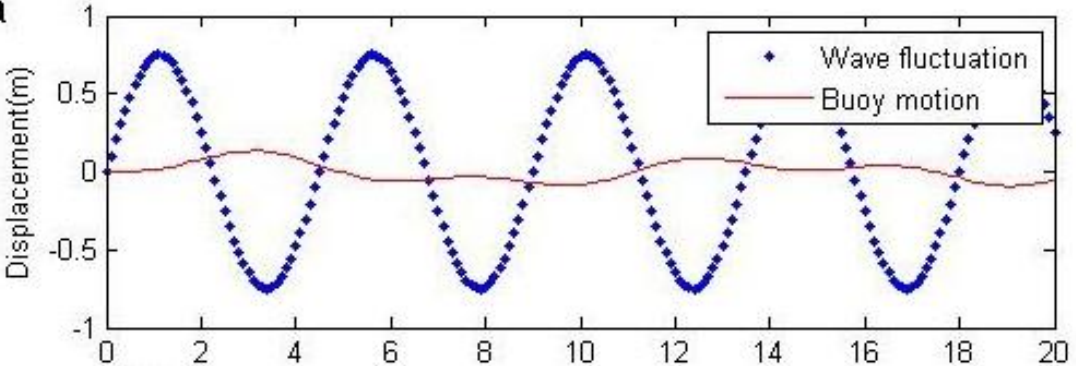

b

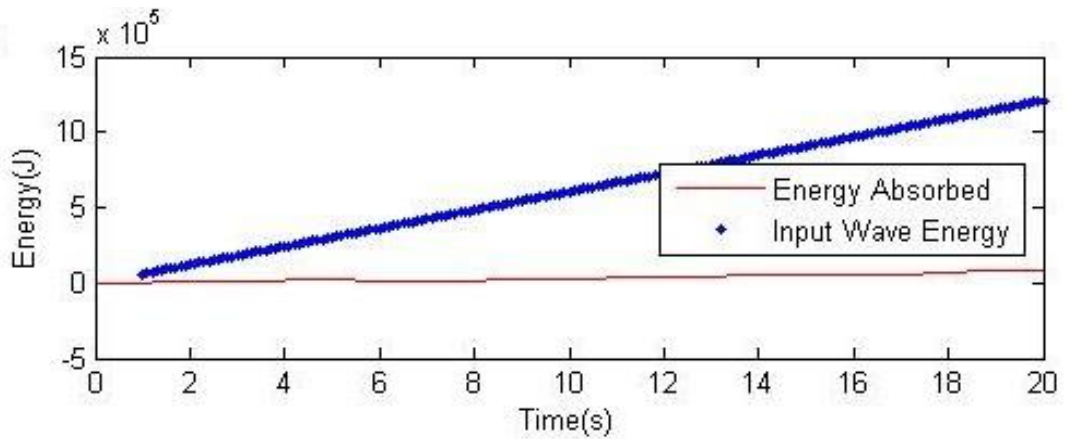

Figure 4. Random radius buoy.

b. Optimal radius buoy

The parameter of the buoy is calculated by using equations (10-11). Inner and outer diameter values are $\mathrm{a} 1=11.6(\mathrm{~m})$ and $\mathrm{a} 2=5.68(\mathrm{~m})$, respectively. In this case, the amplitude of the buoy motion is nearly equal with the amplitude of the wave fluctuation, it is much higher than in case 1 as shown in Fig. 5a. Hence, Most of wave energy could be converted into the kinetic of buoy system, it is confirmed in Fig. $5 \mathrm{~b}$.
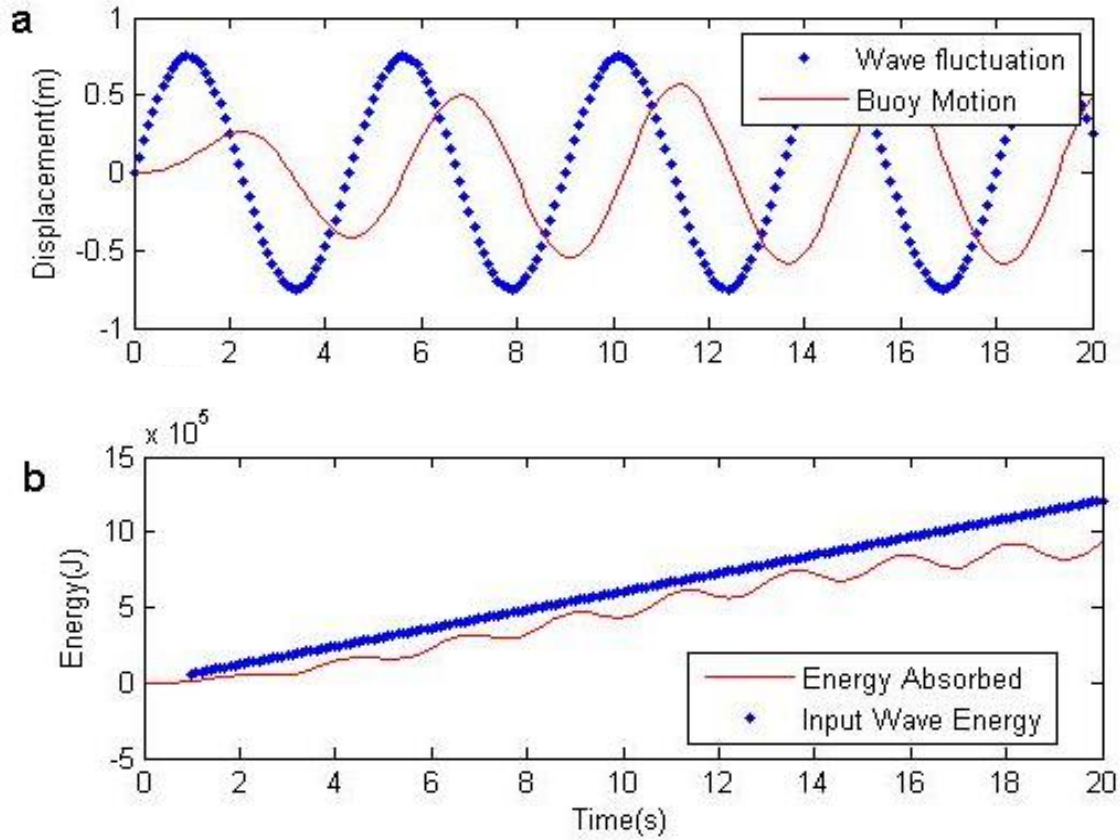

Figure 5. Optimal radius buoy. 


\section{CONCLUSION}

This paper has presented an innovative technology for generating energy from wave energy convertor (HTSWEC). This paper focus on mechanical design concept for floating-buoy system and optimizing the sub buoy's radius in case the shape of the buoy is spherical. The co-simulation environment was realized to verify the energy conversion capability of the suggested model. The simulation results indicate that the proposed model is an effective solution.

\section{REFERENCES}

[1] Soerensen H, Friis-Madsen E, Christensen L, Kofoed JP, Friqaard PB, Knapp W.The results of two years testing in real sea of Wave Dragon. The 6th European Wave and Tidal Energy Conf., Glasgow, 2005, pp. $481 \mathrm{e} 488$.

[2] Evans DV, Falcão AF de O. Hydrodynamics of ocean wave-energy utilization. Berlin: Springer; 1986. pp. $51 \mathrm{e} 55$.

[3] Falcão AF de O, Justino PAP. OWC wave energy devices with air-flow control. Ocean Eng 1999; 26:1249e73.

[4] K M. Vantorrea, R. Banasiakb and R. Verhoevenb. Modelling of hydraulic performance and wave energy extraction by a point absorber in heave. Applied Ocean research 26(204) 61-72.

[5] Falcão AF de O. Falca oModelling and control of oscillating-body wave energy converters with hydraulic power take-off and gas accumulator, Ocean Eng 34(2007) 2021-2032.

[6] Falnes J. Ocean waves and oscillating systems, linear interaction includingwave-energy extraction. UK: Cambridge Univ; 2002. pp. 184e191.

\section{MÔ HÌNH ĐộNG HỌC CỦA HỆ THỐNG BIẾN ĐỔI NĂNG LƯợNG SÓNG BIỂN SỬ DỤNG BỘ TRUYỀN ĐỘNG THỦY TĨNH}

Tóm tắt. Bài báo này sẽ thiết kế một hệ thống biến đổi năng lượng sóng biển sử dụng bộ truyền động thủy tĩnh. Sau đó, xác định bán kính tối ưu của phao sao cho khả năng hấp thu năng lượng của hệ thống là lớn nhất. Trong bài báo này, dữ liệu sóng biển (bước sóng, chu kỳ, chiều cao sóng) được cho trước. Phần mềm Amesim và Matlab/Simulink được sử dụng để mô phỏng quá trình hấp thu năng lượng của hệ thống. Kết quả mô phỏng cho thấy rằng khi phao có bán kính tối ưu thì hiệu quả biến đổi năng lượng sóng biển của hệ thống tốt hơn rất nhiều so với trường hợp phao có bán kính bất kỳ. Cuối cùng, một vài kết luận được trình bày.

Từ khóa. Sóng biển, bộ biến đổi năng lượng, truyền động thủy tĩnh, bán kính tối ưu, hấp thu năng lượng.

Ngày nhận bài: 20/03/2017

Ngày chấp nhận đăng: 08/07/2017 